\title{
Health Promotion for Older People in Hungary: The need for more action
}

\author{
Marzena Tambor ${ }^{1}$, Alicja Domagała ${ }^{1}$, Michał Zabdyr-Jamróz ${ }^{1}$, \\ Iwona Kowalska-Bobko', Agnieszka Sowa ${ }^{2}$, Christoph Sowada ${ }^{1}$, \\ Stanisława Golinowska ${ }^{1,2}$, Petra Baji ${ }^{3}$
}

\author{
${ }^{1}$ Institute of Public Health, Faculty of Health Sciences, Jagiellonian University Medical College, Cracow, Poland; \\ ${ }^{2}$ Department of Social Policy, Institute of Labour and Social Studies, Warsaw, Poland; ${ }^{3}$ Department of Health Econo- \\ mics, Corvinus University of Budapest, Budapest, Hungary
}

Address for correspondence: Marzena Tambor, Jagiellonian University Medical College, Grzegórzecka 20 St., 30-351 Cracow, Poland, marzena.tambor@uj.edu.pl

\section{Abstract}

The health status of the Hungarian population is relatively poor, compared to other countries of similar socio-economic development. Unhealthy diet, smoking, alcohol consumption and low physical activity are important risk factors leading to cardiovascular system diseases - the main cause of death in the general population and among people 65+ in Hungary. Yet, the OECD health statistics indicate that Hungary belongs to a group of countries with the lowest per capita expenditure on prevention and public health and that the level of this expenditure is decreasing.

In Hungary, there is no legislation specifically dedicated to public health (Public Health Act) and the matters of public health and health promotion are regulated by various legal documents. The directions for public health policy are set in National Public Health Programmes. To address the problem of the ageing population, in 2009 a National Ageing Strategy (2009-2034) was adopted. The Strategy stresses the need to develop programmes for prevention, rehabilitation and health promotion for older people.

The main actor in public health policy is the central government, namely its agency the National Public Health and Medical Officer Service. Also, territorial governments play an important role, though they have limited financial capacity to spend on health promotion and they need to rely on external unstable sources of funds when implementing health programmes for older people. NGOs might be important partners for health promotion along with public authorities. However, they require more financial and infrastructural support to be able to perform more activities in the field of health promotion for older people.

Key words: public health, health promotion, older people, healthy ageing, Hungary

\section{Introduction}

The objective of this paper is to present basic information on the organisation and financing of health promotion in Hungary, with the focus on health promotion for older people. Selected activities (good practices) of territorial self-governments and NGOs are described, as these institutions have been recognised as key stakeholders in health promotion for older people in Hungary (for more details on the selection of key institutions in- volved in health promotion for older people in Hungary, see [1]).

Data were collected from desk research. The main sources used were: comparative databases provided by international organisations (particularly by the EU, the OECD and the WHO), scientific papers and grey literature as well as other national materials, including government reports, strategic documents and legal regulations. Moreover, semi-structured interviews with national experts were performed in March-June 2016 based on 
pre-developed guide. The experts indicated good practises of territorial self-governments and NGOs in the area of health promotion for older people and gave in-depth information on these activities.

\section{General context}

Hungary is a high income country, according to the World Bank categorization, located in central Europe. The country is divided into 19 counties (megye) and the capital city Budapest. The counties are further subdivided into municipalities (települések - cities [város] - 328 and villages [község, nagyközség] - 3,126). Budapest is subdivided into 23 districts. Hungary has a population of nearly 10 million inhabitants and more than one quarter of the population lives in the Budapest metropolitan area.

During socialism, the health care system in Hungary, as in other Central and Eastern European countries, was built on the Semashko model with the state in the dominant role. After the political changes of 1990, the Bismarck model was introduced with a single Health Insurance Fund (HIF) administered by the National Health Insurance Fund Administration (NHIFA). NHIFA has been facing continuous deficit since its foundation in 1993 [2]. Since 2010, when center-right government took office, the role of the central government in the provision and financing of health care services has been again strengthened, and HIF budget has been recently reintegrated into the central government budget [3].

Total health expenditure accounts for $7.4 \%$ of GDP (2013) which is below the EU-28 average but higher than in many countries of the Central and Eastern European region (e.g. Poland, Czech Republic). Approximately 65\% of the expenditure comes from public sources. The share of public funding has decreased in the last decade and it is relatively low, compared to other OECD countries.
Private expenditure is mostly made up of out-of-pocket payments. A vast majority of health resources (95\%) is devoted to financing individual health care services and goods (curative care, rehabilitative care, long-term care, ancillary services and medical goods) while collective services (prevention and public health services as well as health administration) take 5\%. The expenditure on prevention and public health services in 2013 accounted for $2.7 \%$ of the total current health expenditure which is lower by 2.3 percentage points than it was in 2000 (see Table I).

\section{Demographic and epidemiologic context}

The share of the older population (65+) in Hungary is slightly below the EU-28 average (see Box 1). However, it is foreseen that an unfavourable demographic tendency will result in a significant increase in the old age dependency ratio from $26.4 \%$ in 2015 to $52.4 \%$ in 2060 . The health status of the Hungarian population is exceptionally low given the general socio-economic development of the country.

The poor health of the Hungarian population has been a highly visible problem for many years. In the first decades of the post-war communist period, efforts in the area of public health (widespread immunisation programmes, public hygiene programmes) resulted in bringing communicable diseases under control and increasing the life expectancy of the Hungarian population [4]. However, starting from the mid-1960s, sanitary and epidemiological services failed to respond to the new health challenges, i.e. non-communicable diseases. This unfavourable trend also continued in the first years after the political change of 1990, when a decline in health status was observed, leaving Hungary not only behind Western European countries, but also some central European countries like Poland and the Czech Republic.

\begin{tabular}{|l|c|c|c|c|c|c|c|c|}
\hline & 2000 & 2005 & 2007 & 2010 & 2012 & 2013 & $\begin{array}{c}\text { Change } \\
2013 \text { to } \\
2000\end{array}$ & $\begin{array}{c}\text { Change } \\
2013 \text { to } \\
2007\end{array}$ \\
\hline $\begin{array}{l}\text { GDP per capita, Forint, Thousands (GDP } \\
\text { price level, 2005) }\end{array}$ & $1,779.5$ & $2,213.9$ & $2,320.6$ & $2,217.1$ & $2,241.7$ & $2,282.2$ & $+28.3 \%$ & $-1.6 \%$ \\
\hline $\begin{array}{l}\text { Total current health expenditure (TCHE) } \\
\text { per capita, Hungarian Forints, Thousands } \\
\text { (constant prices, 2005) }\end{array}$ & 120.9 & 178.9 & 169.1 & 169.8 & 169.1 & 168.2 & $+39.1 \%$ & $-0.5 \%$ \\
\hline $\begin{array}{l}\text { Total current health expenditure (\% of } \\
\text { GDP) }\end{array}$ & 6.8 & 8.1 & 7.3 & 7.7 & 7.5 & 7.4 & $+0.6 \mathrm{pp}$ & $+0.1 \mathrm{pp}$ \\
\hline $\begin{array}{l}\text { Public expenditure (\% TCHE) } \\
\text { Individual health care (\% of TCHE) }\end{array}$ & 92.7 & 93.5 & 93.9 & 93.3 & 95.3 & 95.2 & $+2.5 \mathrm{pp}$ & $+1.3 \mathrm{pp}$ \\
\hline Collective health care (\% of TCHE) & 7.3 & 6.5 & 6.1 & 6.7 & 4.7 & 4.8 & $-2.5 \mathrm{pp}$ & $-1.3 \mathrm{pp}$ \\
\hline $\begin{array}{l}\text { Prevention and public health (\% of } \\
\text { TCHE) }\end{array}$ & 5.0 & 4.5 & 4.3 & 4.5 & 2.8 & 2.7 & $-2.3 \mathrm{pp}$ & $-1.6 \mathrm{pp}$ \\
\hline
\end{tabular}

Table I. Health system indicators. 
In 2014, the share of the older population (65+) in Hungary amounts to $17.5 \%$ and is below the EU-28 average of $18.5 \% .13 .4 \%$ of the population is aged $65-74$ and $4.2 \%$ are the oldest of the old $(80+)$. The proportion of the population aged 65 to 74 in Hungary is equal to the EU-28 average and the proportion of the oldest people is slightly below the EU-28 average of 5.1\% in 2014 [5]. The average life expectancy (LE) at birth for females accounts to 79.1 years of life and is below the EU-28 level of 83.3 years of life. The healthy life years (HLY) for women are estimated at 60.1 (about $76 \%$ of the average female lifespan). The average LE at birth for men is 72.1 years, which is rather low compared to the EU-28 average of 77.8. Healthy life years (HLY) are estimated at 59.1 (which is about $82 \%$ of the average male lifespan). It is worth noting that the gap between the LE of men and women is as large as 7 years of life in the case of LE at birth and almost 4 years of life for the population at the age of 65. The average LE at the age of 65 is 18.4 years for women and 14.5 years for men, which is below the EU-28 averages of 21.3 for women and 17.9 for men. It is estimated that Hungarian women tend to spend only $32 \%$ and Hungarian men $42 \%$ of this time in good health and without disability (HLY at the age of 65).

Due to the increase in the average life expectancy and the decrease in the fertility rate, the proportion of older people (65+) in the population is foreseen to increase from $17.5 \%$ in 2014 to $29.4 \%$ in 2060 . The share of people aged 80 or more in the population is foreseen to triple: from $4.2 \%$ to $12.8 \%$. This unfavourable demographic tendency will result in an increase in the old age dependency ratio from $26.4 \%$ in 2015 to $52.4 \%$ in 2060 .

Box 1. Demography.

Source: Own work.

Presently, the life expectancy at birth for Hungarian men (72.1 years) is nearly 6 years less than the EU-28 average (Box 1). The life expectancy of Hungarian women (79.1 years) is 4 years shorter than among their counterparts in the EU-28. Additional reasons for concern are geographical and social health inequalities [4]. The health status of the older population has also been proven to be worse than in other European countries (Box 2). The European Health and Social Integration Survey (EHSIS) revealed that the prevalence of disability in the Hungarian population of older people is the highest out of all 28 analysed countries (see Figure 1).

Although some efforts have been undertaken, risk factors such as unhealthy diet, smoking, alcohol consumption and low physical activity are important factors shaping the health status of the Hungarian population. They lead to cardiovascular system diseases - the main cause of death in the general population and among people $65+$ (see Box 2).

\section{Legal framework for public health and health promotion in Hungary}

The first important law in Hungary concerning health was passed in 1876 (Act XIV on Public Health). Although titled the Act on Public Health, this act, which declared the state responsible for the health of the population, dealt generally with health protection and the organisation of health care. Nevertheless, public health issues, such as preventing infectious diseases, ensuring access to clean water, housing sanitation, etc. were also covered by this legislation [8]. During the communist period, when the focus was still on communicable diseases, the functioning of the main sanitation institution was regulated by the Council of Ministers Decree No 173/1951 (IX.16) on the organisation of the State Supervisory Agency for Public Hygiene and Infectious Diseases.
In 2014 , the overall mortality level in the population $65+$ is 6,502 deaths per 100,000 population in men and 4,211 deaths per 100,000 in
women [6]. The main causes of mortality in the older population $(65+)$ are cardiovascular system diseases, constituting about $52 \%$ of male
$(3,392 / 100,000$ population) and $58 \%(2,458 / 100,000$ population) of female deaths. Cancers are the cause of about one fourth of deaths in men
$(1,642 / 100,000$ population) and one fifth of deaths in women $(868 / 100,000$ population). Respiratory system diseases account for about $7 \%$ of
male $(447 / 100,000$ population) and $5 \%$ of female $(207 / 100,000$ population) deaths of the population $65+$.
Older people in Hungary report being in poor health status. $32.4 \%$ of people aged $65-74,48.8 \%$ of people aged $75-84$ and $61.2 \%$ of people above
80 years of age assessed their health status as bad or very bad (EU-SILC data of 2014$)$ [5]. Less than $20 \%$ of people aged $65-74,8 \%$ of people
aged $75-84$ and less than $6 \%$ of people above the age of 85 report being in good or better than good health. Long-standing illnesses were reported
by $77.6 \%$ of the population $65+$ in 2014 . Chronic conditions are slightly more common among older women $(79.7 \%)$ than men $(73.8 \%)$ though
the difference between the sexes is not large. The proportion of older people with chronic conditions increases with age. As much as $87.3 \%$ of
people aged 85 or more report suffering from long-standing illnesses. Corporal impairments are the most widespread affecting approximately half
of the population aged 60 to 70 and are more frequent with increasing age as almost $80 \%$ of people $80+$ declare impairments. Vision and hearing
disorders occur in about $10 \%$ of people aged 60 to 70 and in half of the population $80+[7]$. Activity limitations caused by health problems are
reported by $53.4 \%$ of people aged $65-74,72 \%$ of people aged $75-84$ and $83.9 \%$ of people aged 85 or more in 2013 [ 5$]$. Long-standing activity
limitations are reported more frequently by women than men $(56 \%, 76 \%$ and $86 \%$ of women vs. $50 \%, 65 \%$ and $80 \%$ of men in their respective
age groups). The main risk factors of poor health include obesity and inadequate nutrition, lack of physical activity and smoking.

Box 2. Health status.

Source: Own work 


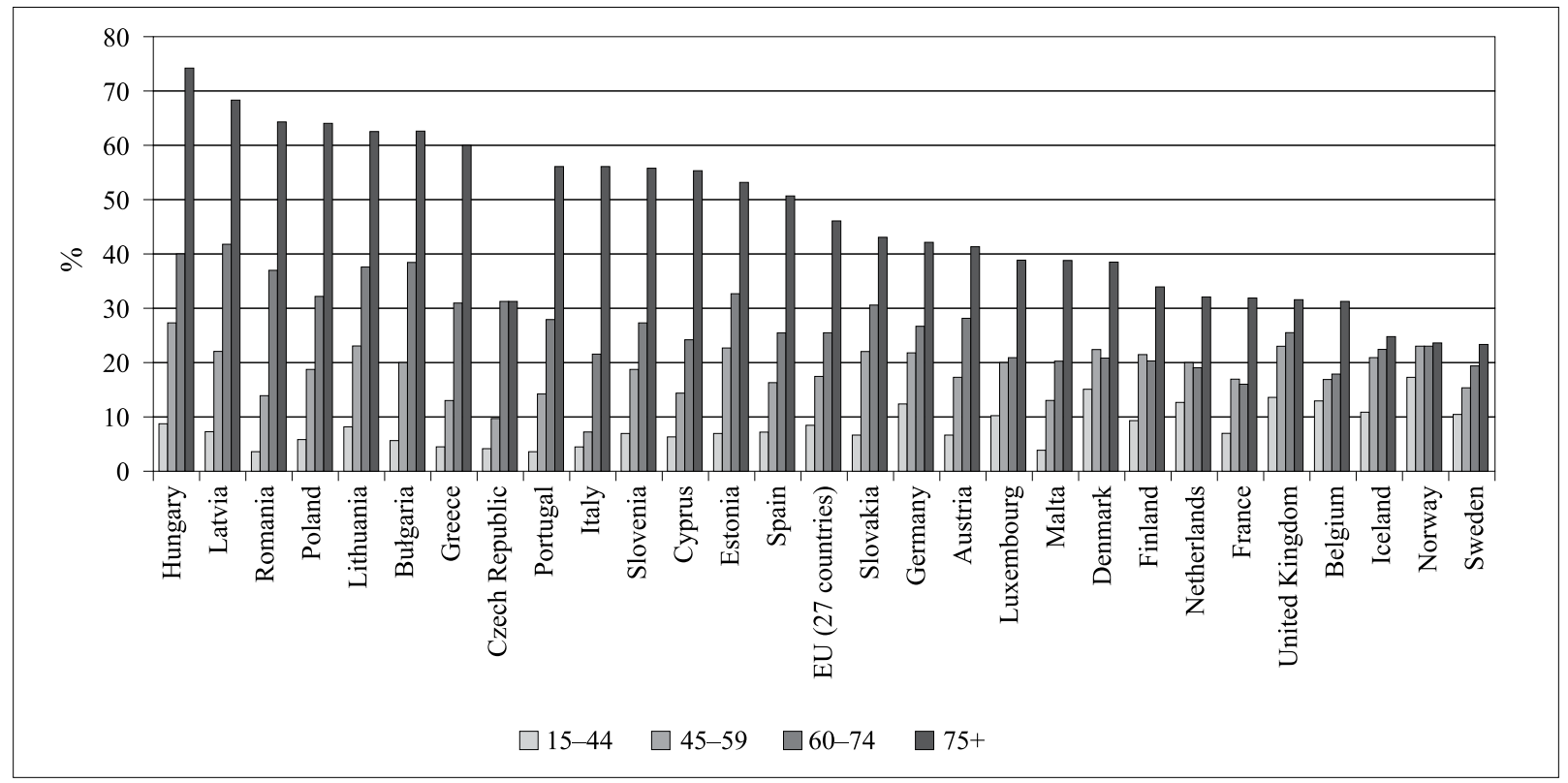

Figure 1. Percentage of disabled by country and age, 2012.

Source: Eurostat. European health and social integration survey (EHSIS), http://ec.europa.eu/eurostat/cache/metadata/en/hlth_ dsb_prve_esms.htm; accessed: 15.12.2016.

Despite the presence of a variety of legislation related to public health and health promotion, Hungary has not yet developed legislation specifically dedicated to public health (Public Health Act). Presently, the legislation which established the main public health institution in Hungary, which is considered the main legislation in the area of public health, is Act XI of 1991 on the National Public Health and Medical Officer Service and the Government, along with Decree No. 362/2006 on the National Public Health and Medical Officer Service and the Designation of the Pharmaceutical Public Administration Authority².

Also, some public health issues are regulated in more general laws on health and health care, such as Act CLIV of 1997 on Health, Act LXXXIII of 1997 on the Services of Compulsory Health Insurance and Act CXXIII of 2015 on Basic Health Care Services. These acts define the health rights of Hungarian citizens, specify the basic service package under the Hungarian health insurance (including health prevention services), and regulate the provision and financing of health care services and the responsibilities of the main public actors. Occupational health protection and the responsibility of employers in protecting the health of their employees are regulated by Act XCIII of 1993 on Occupational Safety. It is also worth mentioning regulations on selected health promotion issues, like the CIII of 2011 on Taxes on Unhealthy Food and Beverages which introduced an earmarked tax for health (see Box 3).

\footnotetext{
- Taxes on Unhealthy Food and Beverages:

Act CIII of 2011 on Taxes on Unhealthy Food and Beverages

It introduces earmarked taxes for the financing of public health programs and health care services. The levy is imposed on high sugar content soft drinks, caffeine added energy drinks, high sugar candies and chocolate products, and some salty snacks and condiments.

- Smoking:

Act CXXXIV of 2012 on Reducing the Prevalence of Smoking Among Young People and Retail Sale of Tobacco Products.

Modifications of Act XLII of 1999 on the Protection of Non-Smokers and Certain Rules on the Consumption and Distribution of Tobacco

Products.

- Health education in schools:

Act CXC of 2011 on National Public Education.

It introduces health education in schools. It obliged the educational institution to create a healthy and secure environment for teaching, promote healthy behaviour (healthy diet and regular physical activity), and to organize regular health checks for children and students (dental, ocular and general screening).

- Public catering in schools:

Decree 37/2014 (IV.30.) on Nutritional Regulations in Public Catering.

It regulates the provision of food by Public Catering Providers and institutions. It specified the amount and quality of food to be provide (forbidding some unhealthy products).
}

Box 3. Important public health legislation since 2010.

Source: Own work. 
The directions for public health policy are set in National Public Health Programmes. The first comprehensive programme was launched as a government resolution in 1994 [9]. It was followed by a renewed public health programme in 2001 'For a Healthy Nation' and in 2003 (after the change of government in 2002), the 'National Programme for a Decade of Health' which set priorities and defined actions for 10 years [10]. The implementation of national public health programmes and the achievements of the defined health objectives have, however, often been hindered by a lack of long-term political support, inadequate financing or insufficient institutional capacity [9].The new national health programme has not been established yet, though a need for such a programme has been indicated in another strategic document on health care established in 2015, 'Healthy Hungary 2014-2020' [11].

Health promotion and disease prevention among the older population in Hungary, has long been recognised as an important health issue which requires more public effort. In 1996, the Committee for Elderly People was established in the Ministry of Health. The committee prepared the Elderly People's Charter. In 2001, the Commissioner of Health Care for Elderly People was assigned with the responsibility of preparing a health care programme for older people based on the charter [12]. In 2003, the ten-year National Public Health Programme 'National Programme for a Decade of Health' was launched with special attention given to problems related to ageing [13]. In 2007, the National Implementation Plan for healthy ageing was prepared, which resulted in various activities promoting healthy nutrition, physical activity and mental health among older people [12].

In 2009 a National Ageing Strategy (2009-2034) was developed and approved by the Hungarian Parliament
[14]. The long-term goals defined in this document include: aligning life expectancy with the EU average; increasing the number of years spent in good health; keeping active in life longer; ensuring financial security in old age; promoting social integration; harmonising different services (healthcare, social, educational, cultural, etc.) considering the interests and needs of the elderly and old people; supporting lifelong learning; promoting active ageing (meaning not only labour activity, but also social, cultural, and civil activity); calling the attention of younger generations to 'age management' and changing the social attitude regarding ageing in an economic and social sense [15]. The Strategy stresses the need to develop programmes for prevention, rehabilitation, health promotion and sports for senior people and underlines the importance of physical activity for older people's health.

\section{Financing public health and health promotion in Hungary}

The OECD health statistics indicate that Hungary, together with other CEE countries, Greece and Mexico, belongs to a group of countries with the lowest expenditure on prevention and public health (see Figure 2). ${ }^{3}$ In 2013 the expenditure was 47.3 US\$ PPP. In the last decade, there has been a decrease in spending on prevention and public health in Hungary. Between 2005 and 2013 the real expenditure per capita decreased by more than $40 \%$ (from 63 US\$ PPP to 36 US\$ PPP) (Table II).

There are various sources of funds for prevention and public health in Hungary (Figure 3 and Figure 4). The expenditure from public sources accounts for $57 \%$ of total expenditure on prevention and public health, though the share of the public expenditure has declined in recent years (by approx. 8 percentage points since 2005)

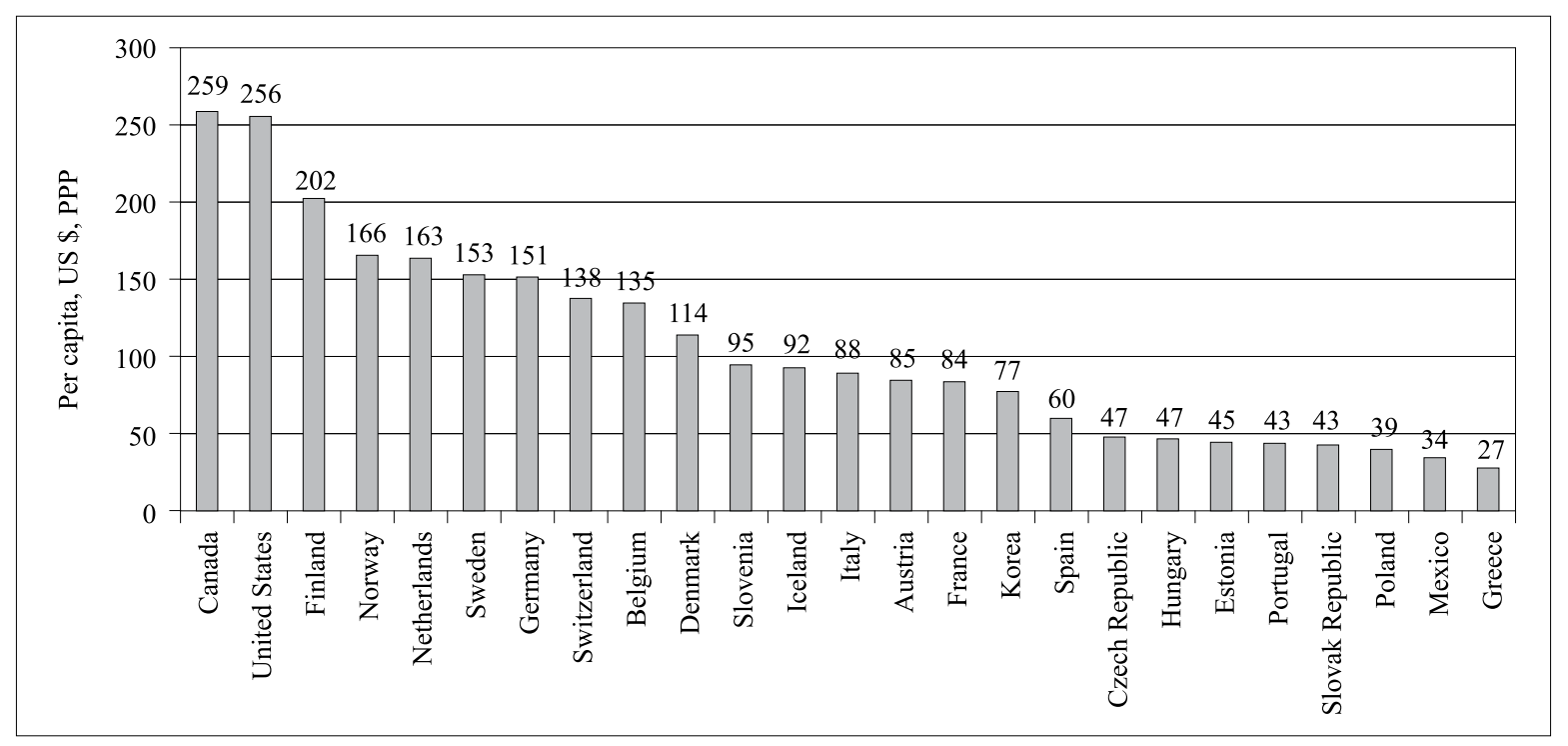

Figure 2. Expenditure on prevention and public health per capita (US\$ PPP) in 2013 in OECD countries.

Source: Based on OECD Health Statistics, http://stats.oecd.org/index.aspx?DataSetCode=HEALTH_STAT\#; accessed: 18.06.2016. 


\begin{tabular}{|c|c|c|c|c|c|c|c|c|c|}
\hline & 2005 & 2006 & 2007 & 2008 & 2009 & 2010 & 2011 & 2012 & 2013 \\
\hline $\begin{array}{l}\text { Total expenditure on pre- } \\
\text { vention and public health } \\
\text { (Hungarian Forints, Millions) }\end{array}$ & $81,140.8$ & $81,155.5$ & $78,225.8$ & 80,409 & $87,522.8$ & $79,220.9$ & $71,015.1$ & $59,630.3$ & 60,467 \\
\hline Per capita, US\$ PPP & 62.6 & 62.7 & 59.2 & 61.9 & 69.6 & 63.1 & 57.1 & 47 & 47.3 \\
\hline $\begin{array}{l}\text { Per capita, US\$ PPP } \\
\text { (constant prices, 2005) }\end{array}$ & 62.6 & 60.5 & 55.5 & 54.4 & 57.1 & 50.7 & 44.6 & 36.4 & 36 \\
\hline \multicolumn{10}{|l|}{ Public expenditure } \\
\hline $\begin{array}{l}\text { Social health insurance (Hun- } \\
\text { garian Forints, Millions) }\end{array}$ & $17,001.2$ & $18,711.4$ & $18,679.8$ & $18,667.2$ & $18,736.7$ & 19,066 & $18,895.1$ & $18,276.7$ & $20,697.8$ \\
\hline $\begin{array}{l}\text { Social health insurance (\% } \\
\text { of total health expenditure of } \\
\text { social health insurance fund) }\end{array}$ & 1.6 & 1.6 & 1.8 & 1.7 & 1.7 & 1.6 & 1.6 & 1.6 & 1.7 \\
\hline $\begin{array}{l}\text { Central government (Hunga- } \\
\text { rian Forints, Millions) }\end{array}$ & $30,739.3$ & $30,492.1$ & $26,425.6$ & $27,157.7$ & $25,626.2$ & $29,304.5$ & $19,573.4$ & n.d. & n.d. \\
\hline $\begin{array}{l}\text { Central government ( } \% \text { of } \\
\text { total health expenditure of } \\
\text { central government) }\end{array}$ & 36.9 & 35.4 & 27.6 & 28.3 & 29.4 & 29.1 & 19.6 & n.d. & n.d. \\
\hline $\begin{array}{l}\text { Territorial government (Hun- } \\
\text { garian Forints, Millions) }\end{array}$ & $5,207.5$ & $3,942.8$ & $4,402.7$ & $4,928.1$ & $3,200.5$ & $3,747.9$ & $4,501.9$ & n.d. & n.d. \\
\hline $\begin{array}{l}\text { Territorial government (\% of } \\
\text { total health expenditure of } \\
\text { territorial government) }\end{array}$ & 7 & 5.6 & 5.1 & 5.4 & 3.4 & 5.8 & 6.4 & n.d. & n.d. \\
\hline \multicolumn{10}{|l|}{ Private expenditure } \\
\hline $\begin{array}{l}\text { Non-profit organisations } \\
\text { (Hungarian Forints, Millions) }\end{array}$ & $6,430.7$ & $6,673.7$ & $7,683.9$ & $6,538.2$ & $8,040.9$ & $7,701.8$ & $7,900.9$ & $6,665.3$ & $7,798.1$ \\
\hline $\begin{array}{l}\text { Non-profit organisations (\% } \\
\text { of total health expenditure of } \\
\text { non-profit organisations) }\end{array}$ & 23.9 & 20.6 & 23.5 & 20 & 22.4 & 19.7 & 19.8 & 18.6 & 22.2 \\
\hline $\begin{array}{l}\text { Corporations (Hungarian } \\
\text { Forints, Millions) }\end{array}$ & $16,257.1$ & $16,375.5$ & $17,263.2$ & 16,402 & $26,815.2$ & $14,313.3$ & $15,064.9$ & $14,417.9$ & $13,121.5$ \\
\hline $\begin{array}{l}\text { Corporations (\% of total } \\
\text { health expenditure of corpo- } \\
\text { rations) }\end{array}$ & 42.8 & 33.8 & 30.5 & 27.1 & 34.2 & 20.3 & 18.8 & 19.7 & 20.4 \\
\hline $\begin{array}{l}\text { Households out-of-pocket } \\
\text { expenditure (Hungarian } \\
\text { Forints, Millions) }\end{array}$ & $3,376.3$ & $2,944.4$ & $2,932.7$ & $5,701.4$ & $4,186.5$ & 4,106 & $4,224.2$ & $3,966.5$ & $5,052.9$ \\
\hline $\begin{array}{l}\text { Households out-of-pocket (\% } \\
\text { of total health expenditure of } \\
\text { households) }\end{array}$ & 0.7 & 0.6 & 0.6 & 1.1 & 0.8 & 0.7 & 0.7 & 0.6 & 0.8 \\
\hline $\begin{array}{l}\text { Private insurance (Hungarian } \\
\text { Forints, Millions) }\end{array}$ & $2,128.8$ & $2,015.5$ & 837.9 & $1,014.4$ & 916.8 & 981.5 & 854.7 & 150.3 & 0.3 \\
\hline $\begin{array}{l}\text { Private insurance }(\% \text { of total } \\
\text { health expenditure of private } \\
\text { insurers) }\end{array}$ & 10.5 & 6.7 & 2.1 & 2.4 & 1.7 & 1.7 & 1.5 & 0.3 & 0 \\
\hline
\end{tabular}

Table II. Expenditure on prevention and public health in Hungary.

Source: Based on OECD Health Statistics, http://stats.oecd.org/index.aspx?DataSetCode=HEALTH_STAT\#; accessed: 18.06.2016.

(Figure 4). Public sources include tax revenues, namely general taxes and taxes on unhealthy food and beverages, introduced in 2011, which also contribute to the health budget [17]. There is no specific allocation of the revenues from excise taxes on tobacco and alcohol to public health, though this has been under political discussion [4]. Some resources from the Health Insurance Fund are also allocated to health promotion or disease prevention, though no sub-budget for this purpose has been distinguished $^{4}[18]$.
The importance of different public revenues for public health has changed in last years (see Figure 3 and Figure 4). Until 2012, the main public sources of funds for prevention and public health were tax revenues. This included expenditure by the central government (on public health programmes, vaccination and the functioning of National Public Health and Medical Officer Services) and to a lesser extent, spending by territorial governments (see Table II). ${ }^{5}$ The latest data indicate however, that expenditure from social insurance outspends the 


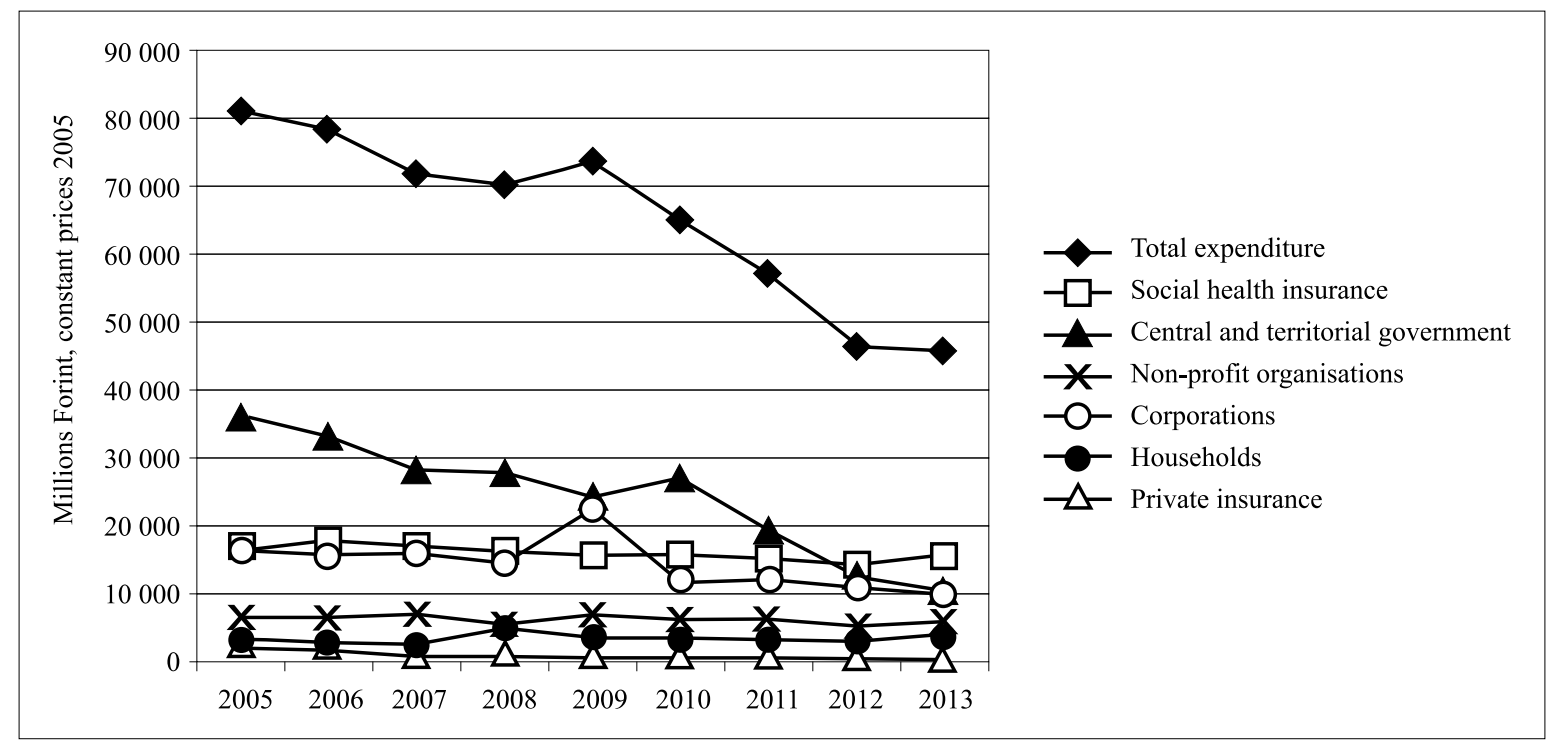

Figure 3. Real expenditure on prevention and public health in Hungary, 2005-2013.

Source: Based on OECD Health Statistics, http://stats.oecd.org/index.aspx?DataSetCode=HEALTH_STAT\#; accessed: 18.06.2016.

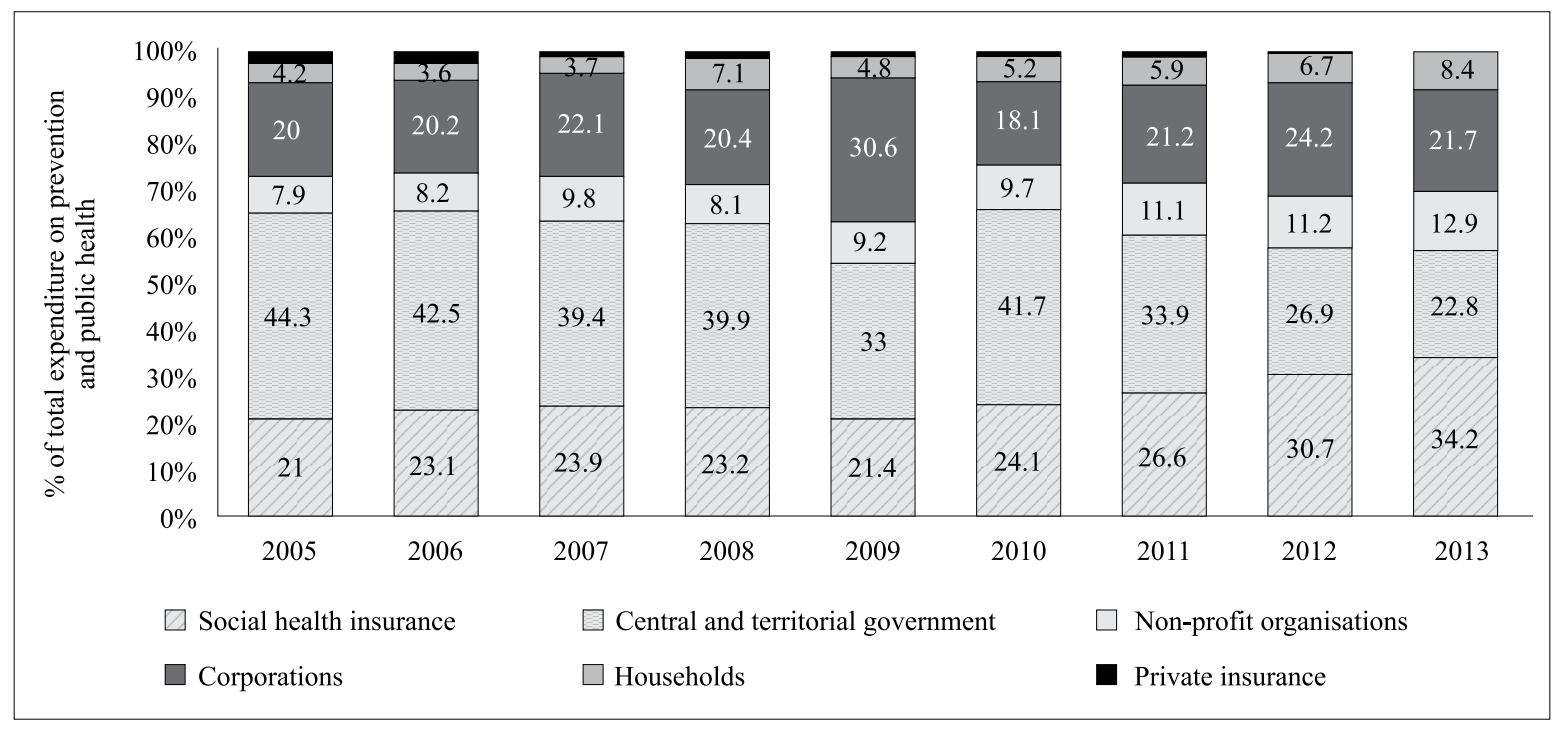

Figure 4. The structure of prevention and public health expenditure by financing agent.

Source: Based on OECD Health Statistics, http://stats.oecd.org/index.aspx?DataSetCode=HEALTH_STAT\#; accessed: 18.06.2016.

expenditure of governments (i.e. in $2013,34 \%$ of total expenditure on prevention and public health came from social insurance and $23 \%$ from tax revenues). This trend was due to a decline in the level of expenditure on prevention and public health by the central government (i.e. between 2005 and 2011, the share of the expenditure by the central government declined from $38 \%$ to $28 \%$ ). It should be noted however, that since 2012 some of the expenditure of the central government on the activities of National Public Health and Medical Officer Services, classified earlier as expenditure on prevention, has been re-classified as administrative spending, which might explain the observed drop [19]. The expenditure of the Health Insurance Fund, on the other hand, has remained stable through the last decade (see Figure 3 ). This includes spending on prevention of communicable and non-communicable diseases; maternal and child health; family planning, and school health services [19].

The main source of private revenues for prevention and public health are corporations (more than 20\% of total expenditure on prevention and public health) (Figure 3). These are resources related to occupational health. However, the level of expenditure by employers on prevention and public health is decreasing in favour 
of expenditure on curative services (in 2005, expenditure on preventive services accounted for more than $40 \%$ of the total health expenditure of corporations, while 8 years later, in 2013 , it was only $20 \%$, see Table II).

The second largest source of private funds for prevention and public health are non-profit organisations. The expenditures of non-profit organisations account for approx. $13 \%$ of the total expenditure on public health and prevention and they are rather stable. Household outof-pocket expenditure on prevention and public health services has been increasing, and in 2013 accounted for more than $8 \%$ of the total expenditure on these services. Resources from private insurance play minor and diminishing role in financing prevention services as preventive services or screenings no longer can be offered in private health insurance packages. Also, declining ratio of private insurance in financing prevention services is due to changes in legislation which promote the use of health savings accounts (egészségpénztárak), and this kind of spending appears as out-of-pocket expenditure.

\section{Institutions involved in public health and health promotion and their programmes addressed to older people}

Public health services are mainly the responsibility of the central government (the Ministry of Human Capacities $^{6}$ ), which provides these services through the National Public Health and Medical Officer Service (NPHMOS). The NPHMOS was established in 1991 [20, 21] as a state agency to address the shortcoming of the traditional sanitary and epidemiological service, which failed to respond adequately to the challenges of noncommunicable diseases. However, the NPHMOS was established on the basis of the State Supervisory Agency for Public Hygiene and Infectious Diseases, with limited professional capacity to become a modern public health institution [22]. This changed later in the 90s when public health professionals, trained at newly formed schools of public health, became available for employment by NPHMOS. ${ }^{7}$ The administration of the NPHMOS was divided into three levels: national, headed by the Chief Public Health Officer, regional (seven regional offices, each covering the population of two to three counties) and sub-regional. Presently, territorial offices have been integrated into the government offices (kormányhivatalok). The NPHMOS has a broad range of responsibilities related to public health (environmental and settlement health, food and nutritional health, children and youth health, radiohygiene and chemical safety), epidemiology (monitoring epidemiological issues and changes in the population's health status), health protection, health education, health promotion, public health administration and occupational health (workplace hygiene, occupational medicine) as well as supervision of healthcare provision. ${ }^{8}$

The NPHMOS is supported by national institutes: the National Public Health Centre, the National Centre for Epidemiology, the Institute for Emergency Healthcare Supply Management, and the National Institute for Health Development. Among them, the National Institute for Health Development (Nemzeti Egészségfejlesztési Intézet, NEFI) is an important methodological background institution of the Ministry of Human Capacities with a mission of 'influencing the health behaviour of the population and providing health related information in the field of public health'.

The territorial governments are key public stakeholders in health promotion for older people in Hungary. They are generally responsible for planning and providing local health services. However, they have limited financial capacity to spend on health (they have no earmarked funds for public health). Even the financing of capital cost, which territorial government are responsible for as the owners of health care facilities, requires subsidies from the central government [4]. Despite the financial barriers, some territorial governments have implemented health promotion programmes targeted at older people, usually with external EU financial aid, which are considered good practice (See Box 4-6).

Central and territorial self-governments fulfilling their responsibilities for health promotion among older people rely on the support of non-governmental partners, particularly NGOs. In the early 2000s, Hungary was considered a Central-Eastern European leader in legislation on NGO activities [23]. As of 2014, there were about 65,000 NGOs registered in Hungary ${ }^{12}$ [25]. This number has increased since 2007 by approx. 3,000. Nevertheless, in that year only $4.7 \%$ of NGOs operated in the field of health and $9 \%$ in social services, $15.7 \%$ were active in education and $12.2 \%$ in sports and recreation.

A survey from 2000 indicated that about $20 \%$ of local self-governments had contracts with NGOs, delegating public services [25]. Public grants constitute a significant source of income for the NGO sector. ${ }^{13}$ In 2007, $35 \%$ of the total sector income came from state or local grants [25]. These resources are distributed through calls for proposals and are funded from the National Civil Fund (i.e. a fund established by the Hungarian government in 2003, specifically in order to support NGOs). Yet, there are some critics on the over-politicisation and extensive bureaucracy of the state funding distribution to NGOs which threatens the sustainability of NGO's funding $[23,26]$.

An example of collaboration between the government and NGOs in the field of health promotion for the older population, is the 'Walking Club for Healthier Ageing' programme for pensioners over the age of 60 . The programme promotes physical activity through club activities and supplements this with lectures on healthy ageing, culture, and other topics. ${ }^{14}$ Another example - often indicated as a good practice - is 'Basic social services in rural settlements: Village and remote homestead community care-giving'. This programme functions within governmental policy addressed to excluded older people but it also involves civil society resources, and especially social networks. It is a multi-sectorial operation with a complex structure of activities which also has proven to be exemplary due to its low cost and high transferability [27]. Box 6 includes other examples of good practices by NGOs. 


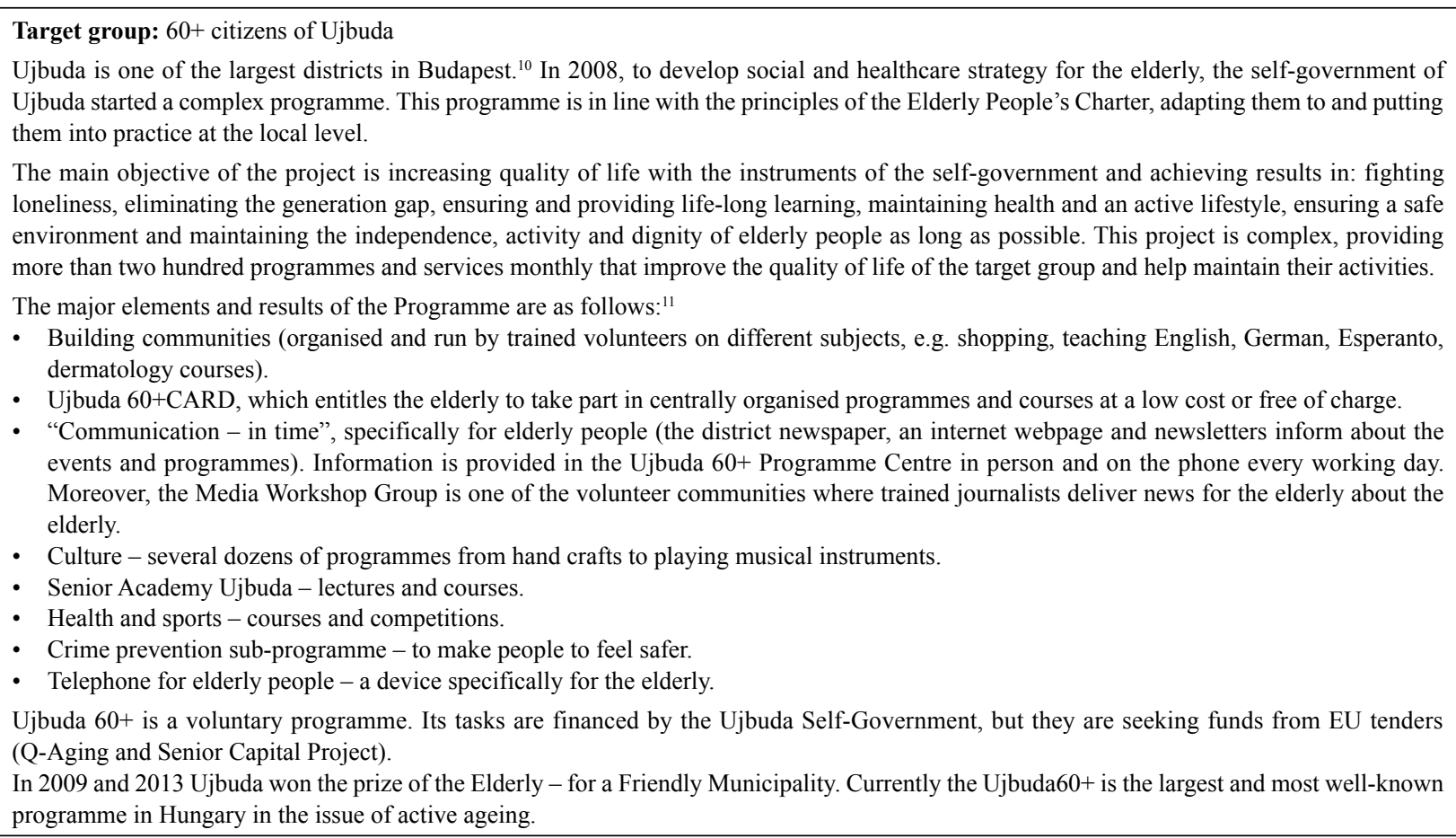

Box 4. Municipality of Ujbuda's Programme for Elderly People 60+.

Source: On the basis of information and materials presented by Ilona Gyorffyne Molnar (the Head of Citizen's Services Directorate of the Local Government \& the Municipality of District 11 of Budapest) during the European Congress of Regional and Local Governments in Krakow, 5 April 2016.

\section{Target group: $60+$ senior citizens}

In Zugló (the 14th district of Budapest), in the framework of the Silver City pilot project, the Zugló Age Centre was created. This centre helps in solving the problems of the elderly, making the most of their activity potential, processing their suggestions related to community life, and communicating those to the local government authority or government organisations.

The Zugló Age Centre offers complex activities dedicated to older people: Infopoint, volunteering, andragogy (a series of scientific lectures in the form of a free university) and a community building. One of the crucial services offered for the elderly is the ability to gain information about the initiatives/activities of district offices, civil or church organisations. The Infopoint ensures the accessibility of the offered programmes, their connections and the rules of participation in the programmes. They also collect feedback (suggestions/questions) regarding the programmes. One of the main conditions of the Age Centre is that participants feel involved in the issues of the elderly of Zugló.

Box 5. Zugló Age Centre (the 14th district of the Capital City, Budapest).

Source: http://budapesttimes.hu/2014/09/19/in-the-silver-city-communities-there-are-more-opportunities; accessed: 15.04.2016.

\section{Target Group: Older people (60+)}

The Budapest Cultural Centre (BCC) is a professional service institution of the community cultural institutions, civil organisations and communities in the 11th District of Budapest. In 2006, the BCC implemented a computer learning programme for older people by developing and sponsoring the Click on it Grandma programme, which helps senior citizens and retired people overcome the main obstacles of computer and Internet usage. The practice-oriented training courses offered by the $\mathrm{BCC}$ are specially developed for and targeted at meeting the special needs of older people. The BCC is an educational methodology centre targeted at meeting the needs of senior citizens and has also established good relations with all local cultural and community centres nationwide. Since 2006 the BCC has extended the programme beyond Budapest and set up a nationwide educational network to launch courses franchised, administrated and supervised by the BCC. Now this is the largest programme of its kind in Hungary and is run in 12 cities.

In 2013 the BCC implemented the intergenerational Project: "Granny - Student IT Study Circle." Older and younger people meet regularly in the BCC. During the meetings older people acquire new IT skills and thanks to the length of the meetings they have a chance to put the newly acquired knowledge into practice. The BCC encourages the elderly to start learning or volunteering.

According to BCC analysis, the senior education structure in Hungary needs to be further developed and improved. The central and local health promotion initiatives need to be further supported. Participation in such activities stimulates personal development, builds self-esteem, allows for better communication and reduces social exclusion.

Box 6. Budapest Cultural Centre (BCC) Budapest, XI. District Etele út 55.

Source: https://joinup.ec.europa.eu/community/epractice/case/click-it-grandma; accessed: 13.04.2016. 
- 'Learning through Volunteering in Senior Age' - a project that focuses on enhancing lifelong learning by knowledge exchange and inter-generational dialogue. The side goal of this initiative is to combat national prejudices. ${ }^{15}$

- The activities of the non-profit company TMSZK (Társadalomfejlesztési Módszertani és Szolgáltató Központ Nonprofit Kft.) that is a professional-methodology centre providing 'aid to its collaborative partners to reduce the negative social, economic and cultural effects triggered mainly by ageing as a process'. It offers professional and methodological assistance primarily to elderly and senior citizens, employers, state organisations and institutes, local governments and civil organisations covering certain areas. ${ }^{16}$

- 'Seniors Club' - Retired Teachers' Association together with other institutions organised IT training, museums visits, community meetings and various other joint programmes for the elderly. ${ }^{17}$

Box 7. Health promotion for older people - good practices by NGOs.

Source: EuroHealthNet, Healthy and Active Ageing (Report), Bundeszentrale für gesundheitliche Aufklärung, Brussels 2012, http:// www.healthyageing.eu/sites/www.healthyageing.eu/files/resources/Healthy\%20and\%20Active\%20Ageing.pdf; OEFI, 'Országos Egészségfejlesztési Intézet'; accessed: 15.05.2016 [28].

\section{Conclusions and recommendations}

The results of our review indicate that health promotion is a neglected area in the Hungarian health care system. Hungary belongs to the group of countries with the lowest expenditure on prevention and public health and the level of this expenditure is decreasing. There is no separate fund for public health which does not allow the securing of sufficient financial resources for health promotion programmes. Moreover, the lack of legislation specifically dedicated to public health diminishes the importance of this area of the health system. However, given the poor status of the Hungarian population, which can largely be attributed to an unhealthy lifestyle, greater policy attention to health promotion is highly warranted.

The important target group for health promotion activities should be the elderly population, which will be increasing in size in the coming decades. As evidence indicates, this group is characterised with very low health status. The need for paying greater attention to older people has been already recognised by the Hungarian government, which developed a National Ageing Strategy. Still, programmes focused on health promotion are lacking.

There are various barriers to the implementation of health programmes in Hungary. Along with the earlier mentioned resource constraints, a lack of political commitment to pursue health programmes, especially if inherited from political predecessors, might be also a hindering factor. Although non-public institutions such as NGOs, can be valuable partners in health ageing policies for the government and territorial self-governments, more commitment and support is needed to ensure a greater prevalence and sustainability of health promotion initiatives targeted at older people.

\section{Notes}

${ }^{1}$ The ratio between the number of persons aged 65 and over (the age when they are generally economically inactive) and the number of persons aged between 15 and 64. The value is expressed per 100 persons of working age (15-64) (Eurostat).

${ }^{2}$ The list of compulsory and discretionary screening programmes is included in Decree No. 51/1997 (XII.18.) NM of the Minister of Welfare on Preventive and Early Diagnostic Services that Can be Utilised in the Frame of the Social He- alth Insurance System and on the Certification of Participation in Screening Programmes. Decree No. 18/1998 (VI.3) NM of Minister of Welfare on the Prevention and Control of Infectious Diseases and Epidemics regulates the operation of surveillance systems for communicable diseases, immunisation against communicable diseases and the procedures of infectious disease control.

${ }^{3}$ It should be noted that the data on expenditure for prevention and public health include various expenditures and their comparability across countries is limited [16].

${ }^{4}$ The HIF is divided into more than 30 sub-budgets according to the type of service.

${ }^{5}$ This expenditure also includes resources from external sources (EU grants) for funding health promotion, which have been increasing in last decade.

${ }^{6}$ The Ministry of National Resources was created in 2010 by merging five ministries responsible for social, family and youth affairs; health care; education; culture; and sport. These ministers are now represented by State Secretariats (including the State Secretariat for Healthcare), led by a Minister of State [4].

${ }^{7}$ The first School of Public Health was established at the University of Debrecen in the framework of the 'Health Services and Management Programme' (1993-2000) [9].

${ }^{8} \mathrm{https}: / / w w w . a n t s z . h u /$ en/about_us; accessed: 15.06.2016.

${ }^{9} \mathrm{http}: / /$ www.oefi.hu/missio_en.htm; accessed: 15.06.2016. According to the plans of the government, this institute together with some other institutes, is going to be integrated into the National Healthcare Service Centre at the beginning of 2017 (see: Feller A., Gaal P., Velkey Z., Major reorganization among the background institutions of the Ministry of National Resources, http://www.hspm.org/countries/hungary25062012/livinghit. asp $x$ ?Section $=2.3 \% 20$ Organization $\&$ Type $=$ Section; accessed: 3.01.2017).

${ }^{10} 142,000$ citizens, 42,000 of whom who have reached the age of 60 .

${ }^{11} \mathrm{http}: / / w w w . u j b u d a . h u / u j b u d a / s o k a n-v o l t a k-a-60$-gyaloglo-program-elso-setajan; accessed: 15.04.2016.

${ }^{12}$ NGOs in Hungarian are usually referred to as "civil organisations" (civilszervezet). They can have the legal form of an association (egyesület) or a foundation (alapítvány). There are also non-profit companies (general partnerships, limited partnerships, limited liability companies, or shareholder companies). These three categories can be qualified as Public Benefit Organisations (PBO). Hungarian law introduced two tiers of PBO status: 'basic' and 'prominent.' The latter enables 
participation in local self-government responsibilities. PBOs can receive public grants and subsidies and citizens can donate them $1 \%$ of their income tax. In 2012, 53\% of NGOs had PBO status; and approx. $8 \%$ of NGOs had the status of 'prominent' PBOs.

${ }^{13}$ Financing of NGOs in Hungary comes from several sources. This includes individual and corporate donations, including the ' $1 \%$ of tax' and members' contributions, but also grants from governmental institutions and foreign organisations.

${ }^{14} \mathrm{http}: / /$ www.ofi.hu/; accessed: 15.04.2016.

${ }^{15} \mathrm{http}: / /$ www.onkentes.hu/; accessed: 15.04.2016.

${ }^{16} \mathrm{http}: / / \mathrm{www} . \mathrm{tmszk} \cdot \mathrm{hu} / \mathrm{en} /$ introduction/; accessed: 15.04.2016.

${ }^{17} \mathrm{http} / / /$ www.oefi.hu/; accessed: 15.04.2016.

\section{References}

1. Sitko S.J., Kowalska-Bobko I., Mokrzycka A. et al., Institutional analysis of health promotion for older people in Europe. Concept and research tool, "BMC Health Services Research" 2016; 16 (5): 327.

2. Boncz I., Sebestyén A., Financial deficits in the health services of the UK and Hungary, "Lancet" 1006; 367 (9528): 2047-2048.

3. Gaál P., Recent changes of the organizational structure of the Hungarian health care system (2010-2015), "The Health Systems and Policy Monitor. Health Systems in Transition (HiT)" 2016, profile of Hungary, http://hspm. org/countries/hungary25062012/livinghit.aspx?Section= $2.4 \% 20$ Decentralization $\% 20$ and $\% 20$ centralization\& Type $=$ Section $\# 5$ Recentchangesoftheorganizationalstructure oftheHungarianhealthcaresystem(2010-2015); accessed: 28.12.2016.

4. Gaál P., Szigeti S., Csere M., Gaskins M., Panteli D., Hungary health system review, "Health Systems in Transition" 2011; 13 (5): 1-266.

5. Eurostat data; http://ec.europa.eu/eurostat/data/database; accessed: 30.03 .2016 .

6. European health for all database (HFA-DB) WHO Regional Office for Europe, http://data.euro.who.int/hfadb/; accessed: 2.04.2016.

7. Daróczi E., Ageing and health in the transition countries of Europe. The case of Hungary, United Nations Expert Group Meeting on social and economic implications of changing population age structures, 2005, http:// www.un.org/esa/population/meetings/EGMPopAge/ EGMPopAge_10_EDaroczi.pdf; accessed: 15.05.2016.

8. Székely S., On the preparation of the Hungarian Health Act of 1876, "Comm. Hist. Artis Med." 1973; 66-68: 59-84, http://orvostortenet.hu/tankonyvek/tk-05/ pdf/4.20.6/1973_066_068_szekely_sandor_preparation hungarian.pdf, accessed: 15.09.2016.

9. Ádány R., Vokó Z., Hungarian public health - ups and downs in the last 20 years, "The European Journal of Public Health" 2014; 24 (3): 352-353.

10. Resolution No. $46 / 2003$. (IV. 16.) OGY of the National Assembly on the Johan Béla National Programme for a Decade of Health, http://ec.europa.eu/health/ph_determinants/socio_economics/documents/hungary_rd01_en.pdf; accessed: 15.06.2016.

11. Decree No 1039/2015. (II.10.) on the acceptance of the sectorial strategy "Healthy Hungary 2014-2020", http://
www.kormany.hu/download/e/a4/30000/Eg\%C3\%A9 szs $\%$ C3\%A9ges_Magyarorsz\%C3\%A1g_e $\%$ C3\%BC_ strat\%C3\%A9gia_pdf; accessed: 15.06.2016.

12. Wood-Ritsatakis A., Makara P., Gaining health: analysis of policy development in European countries for tackling non-communicable diseases, WHO Regional Office Europe 2009.

13. National Programme for a Decade of Health, http:// ec.europa.eu/health/ph_determinants/socio_economics/ documents/hungary_rd01_en.pdf; accessed: 15.06.2016.

14. Resolution No 81/2009 (X.2) of the Parliament on the National Ageing Strategy. Resolution 1087/2010 (IV.9) on National Ageing Strategy Implementation Plan I. 2010-2012, http://mkogy.jogtar.hu/?page=show\&docid= a09h0081.OGY; accessed: 15.06.2016.

15. Human rights of older persons in Hungary, Information for the Office of the United Nations High Commissioner for Human Rights on the promotion and protection of the human rights of older persons, https://www.google.pl/url?sa=t\&rc $\mathrm{t}=\mathrm{j} \& \mathrm{q}=\&$ esrc $=\mathrm{s} \&$ source $=$ web\&cd $=1 \& \mathrm{cad}=\mathrm{rja} \&$ uact $=8 \& \mathrm{v}$ ed=0ahUKEwj35d_BufLRAhVrIJoKHQU4AlwQFggcM AA\&url=http\%3A\%2F\%2Fwww.ohchr.org\%2FDocumen ts\%2FIssues\%2FOlderPersons\%2FPublicConsultation 20 $13 \% 2 \mathrm{FHungary} \cdot$ doc\&usg=AFQjCNFB0E3tfQ6VZYCu i4Y0veFCXRQFw\&sig2=jh6MzPG7KERoGBV-gpFk4g, accessed: 02.02.2017.

16. Rechel B., McKee M., Facets of public health in Europe, McGraw-Hill Education (UK), Maidenhead Berkshire 2014.

17. Cornelsen L., Carreido A., Health-related taxes on foods and beverages, "Food Research Collaboration" 2015, http:// foodresearch.org.uk/wp-content/uploads/2015/05/Foodand-beverages-taxes-final-20-May-2015.pdf; accessed: 15.07.2016.

18. National Health Insurance Fund Administration, Statistical Yearbook 2014, Budapest 2015, http://site.oep.hu/statisztika/2014/pdf/Evk14_e.pdf\#pagemode=bookmarks\&view $=$ FitH\&page $=1$; accessed: 15.06 .2016

19. OECD methodological explanations. SHA 2015, http:// stats.oecd.org/index.aspx?DataSetCode=HEALTH STAT\#; accessed: 18.06.2016.

20. Act XI of 1991 on the National Public Health and Medical Officer Service (promulgated: 09.04.1991).

21. Decree No 7/1991. (IV.26.) NM of the Minister of Welfare on the Organisation and Operation of the National Public Health and Medical Officer Service.

22. European Observatory on Health Care Systems, "Health Care Systems in Transition" Hungary 1999.

23. Hadzi-Miceva K., Legal and Institutional Mechanisms for NGO-Government Cooperation in Croatia, Estonia, and Hungary, "Int'1 J. Not-for-Profit L. 2007; 10: 43, http:// www.icnl.org/research/journal/vol10iss4/art_1.htm; accessed: 15.05.2016.

24. EC, Civil Society in Hungary, https://ec.europa.eu/europeaid/civil-society-hungary_en; accessed: 15.04.2016.

25. EC, Study on Volunteering in the European Union. Country Report Hungary (European Commission, 2012), http:// ec.europa.eu/citizenship/pdf/national_report_hu_en.pdf; accessed: 15.04.2016.

26. GAN Integrity Vision Team. Hungary Corruption Report, 2016, http://www.business-anti-corruption.com/country- 
profiles/europe-central-asia/hungary/civil-society.aspx; accessed: 15.04.2016.

27. Halloran J., Calderón Vera K., Basic Social Services in Rural Settlements - Village and Remote Homestead Community Care-Giving. Synthesis Report. Peer Review in the Field of Social Inclusion Policies European Social Network - European Commission DG Employment, Social Affairs and Equal Opportunities, 2005.
28. EuroHealthNet, Healthy and Active Ageing (Report), Bundeszentrale für gesundheitliche Aufklärung, Brussels 2012, http://www.healthyageing.eu/sites/www.healthyageing.eu/files/resources/Healthy $\% 20$ and $\% 20$ Active $\% 20$ Ageing.pdf; OEFI, 'Országos Egészségfejlesztési Intézet'; accessed: 15.05.2016. 